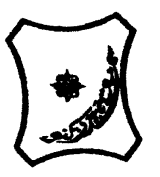

Bayero Journal of Pure and Applied Sciences, 10(1):664 - 669

ISSN 2006 - 6996

\title{
RELATIONSHIP BETWEEN PHYSICOCHEMICAL PARAMETERS AND ZOOPLANKTONS IN KARIDNA RESERVOIR, KADUNA STATE
}

\author{
Abdulazeez, M.T., Bello, A.H., Alhassan, N. and Wada, Y. \\ *Biology Department, Federal College of Education Zaria Nigeria \\ limnology9@gmail.com; 08064421902
}

\section{ABSTRACT}

The study was conducted for a period of one year between October 2013 and September 2014 with the aim to establish the relationship between physicochemical parameters and zooplanktons in Karidna Reservoir. Five sampling stations were chosen; the physicochemical and biological parameters were determined using standard methods, procedures and instruments. The results obtained for the physico-chemical parameters indicated that $\mathrm{pH}$ (6.19-8.63), Temperature (25.94$\left.31.54^{\circ} \mathrm{C}\right)$, Electrical Conductivity $(38.20-64.20 \mu \mathrm{S} / \mathrm{cm})$, Total Dissolved Solids (19.20-37.20 mg/l), Transparency $(19.40-40.10 \mathrm{~cm})$ Dissolved Oxygen $(2.40-6.81 \mathrm{mg} / \mathrm{L})$, Hardness $(3.48-174.4 \mathrm{mg} / \mathrm{L})$ Calcium (2.14-3.86mg/L), Biological Oxygen Demand (2.91-40.85mg/L), Chloride (2.28-3.58mg/L) Phosphate-phosphorus $(0.04-0.24 \mathrm{mg} / \mathrm{L})$, Nitrate- Nitrogen $(0.14-0.30 \mathrm{mg} / \mathrm{L})$, Sulphate $(0.06-$ $0.21 \mathrm{mg} / \mathrm{L})$ Alkalinity (2.51-5.04mg/l). $\mathrm{PO}_{4^{-}}, \mathrm{NO}_{3^{-}}, \mathrm{SO}_{4^{-}}, E C, T D S$, Transparency, D.O and B.O.D were highly significant at $(P \leq 0.01)$ between the seasons while non-significant differences were observed in $\mathrm{Cl}$, Hardness, Alkalinity, Temperature and $\mathrm{pH}$. It was only Calcium that was significant at $(P>0.01)$. Zooplankton samples were collected with silk plankton net of $25 \mathrm{~cm}$ diameter of $70 \mu \mathrm{m}$ meshes attached with a bottle of $50 \mathrm{ml}$ capacity at the base and collection of samples of zooplanktons through vertical hauling. Five different groups of zooplankton were identified in this study where Rotifera group represented as the most dominant group securing seven genus. Almost all groups of zooplankton were found at a higher number in the wet season whereas dry season represented the lowest number of them. Zooplanktons of all groups were positively correlated with calcium and $\mathrm{pH}$. Effective monitoring of the parameters of the reservoir and regulation of domestic activities in and around the reservoir are recommended in order to slow down the aging process and conserve its biodiversity for a longer period.

Keywords: Zooplanktons, Karidna Reservoir, Physicochemical Parameters, Plankton net, Hanan Instrument

\section{INTRODUCTION}

The quality of water in any ecosystem provides significant information about the available resources for supporting life in that ecosystem. Good quality of water resources depends on a large number of physic- chemical parameters and biological characteristics to assess the monitoring of these parameters is essential to identify magnitude and source of any pollution load(Venkatesharaju et al., 2010). These characteristics can identify certain condition for ecology of living organism and suggest appropriate conservation and management strategies (Ekiye and Zejiao, 2010).

Zooplanktons are microscopic aquatic life forms having little or no resistance to currents and are therefore free floating or suspended in open or pelagic waters (Thirupathaiah,2012). While some forms of zooplankton move by vertical migration, their horizontal position is mostly determined by current movements of the body of water they inhabit (Beyruth, 2010).They are being considered as water quality indicator in aquatic environment from many years ago. Some species flourish in highly eutrophic water while others are very sensitive to organic or chemical wastes. Because of their short life cycles, planktons respond quickly to environmental changes and species composition are more likely to indicate the quality of water mass in which they are found. They have a profound influence on certain non-biological aspects of water quality, such as color, odor and taste (Mustapha, 2011). In addition, eutrophication of coastal areas can be severe since these areas act as natural filters for suspended sediments and nutrients coming from the land to the open sea. The most apparent effects are the proliferation of harmful algal blooms and the hypoxia due to insufficient number of zooplankton. Thus zooplankton can speak to the condition of the water and can be used to assess overall water body health. 
Moreover, they play a vital role in the aquatic ecosystem by forming an important link in the food chain from primary to tertiary level leading to the production of fishery (Mustapha, 2010). This paper therefore aims to investigate the relationship between the physico chemical parameters and distribution of zooplanktons in Karidna Reservoir.

\section{MATERIALS AND METHODS \\ Study Area}

Karidna reservoir is located in College of Agriculture and Animal Science (CAAS) Mando, Igabi local government Kaduna State. The study area occupies some $406.39 \mathrm{~m}^{2}$ within latitudes $10^{\circ}$ $37^{\prime} 12^{\prime \prime}-10^{\circ} 37^{\prime} 36^{\prime \prime} \mathrm{N}$ and longitude $7^{\circ} 25^{\prime} 12^{\prime \prime}$ $7^{\circ} 25^{\prime} 36^{\prime \prime} \mathrm{E}$.

The reservoir catchment lies within the tropical wet and dry climatic zone, characterized by strong seasonality in rainfall and temperature distributions. It has two distinct seasons, the dry season (October to March) and wet season (April to September). The area has a single maximum rainfall regime with average annual totals ranging from $1050 \mathrm{~mm}$ to $1250 \mathrm{~mm}$

Sampling Procedures

Five sampling stations were chosen within the water reservoir as follows:

Station 1: $\quad$ Area round the entrance where human activities like bathing, washing, irrigation farming and animal activities are taking place.
Station 2: $\quad$ At the lower point where there are less human activities.

Station 3: At the deepest part of the reservoir and

Station 4 and 5 at the longest part of the reservoir.

Samples were collected for a period of twelve months. Water samples were collected from six sampling stations between the hours of 8:00 am to $1: 00 \mathrm{pm}$. In this method, water was sampled at surface level by dipping 1 litre plastic sampling bottle and slides over the most upper surface of water with their mouth against passage of the water into the bottle (APHA, 2005).

Some parameters were determined insitu using Hanan Instrument of model ( $\mathrm{HI} 98129)$ such as the Temperature, pH, Electrical conductivity and Total dissolved solids while some were transported to the laboratory for the analysis of physico-chemical parameters using standard methods (APHA, 2005)

\section{Determination of Water Transparency}

The transparency of the water was measured using $20 \mathrm{~cm}$ diameter Secchi disk, which was dipped into the water till the disk disappeared and the depth was recorded, it was then dipped further and then withdrawn carefully and the depth at which it became visible was also recorded. Actual measurement was obtained by taking the average of the two readings (APHA, 2005).

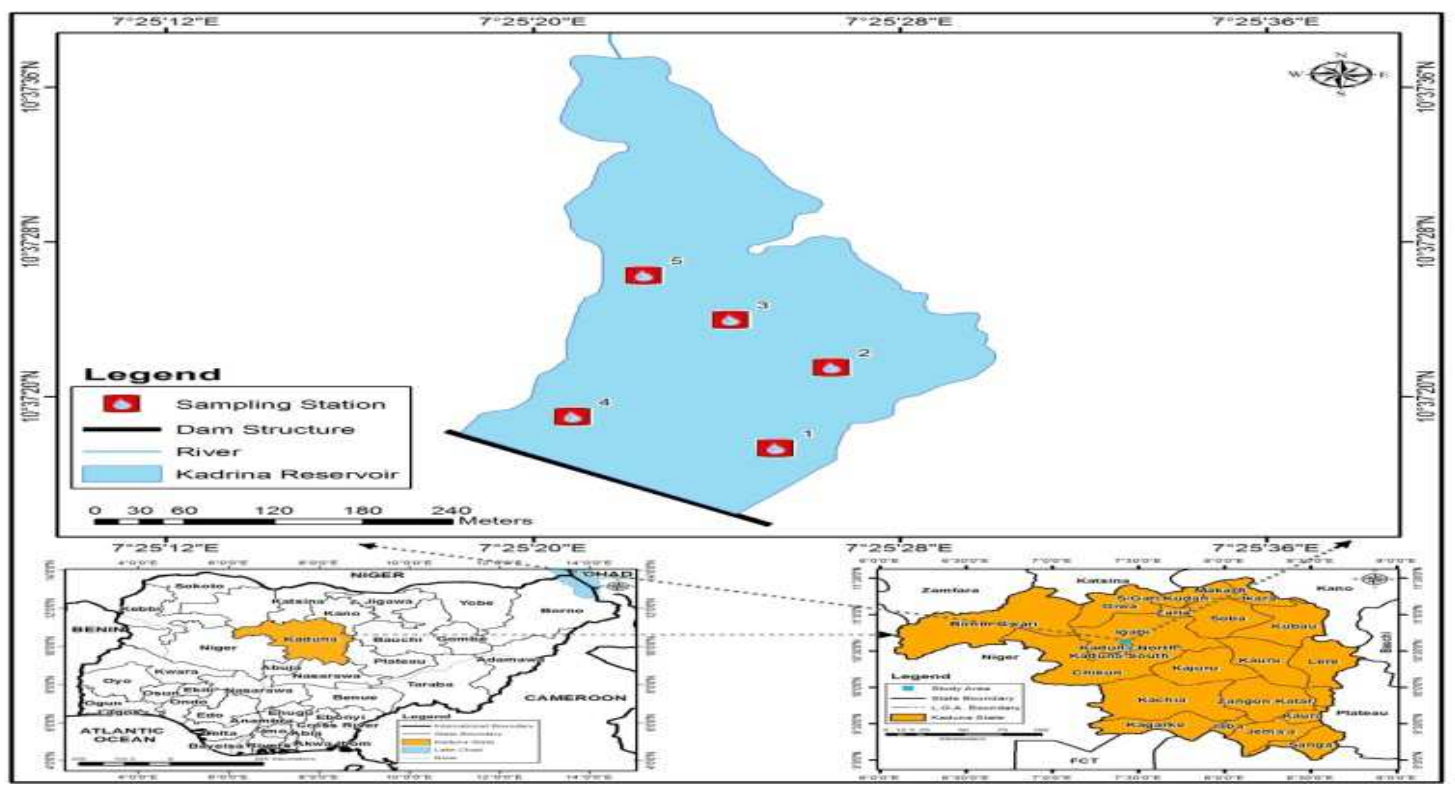

Figure 1: Map of Kadrina Reservoir showing Sampling Stations

Source: Fieldwork/Administrative Map of Igabi L.G.A., Kaduna State. 
Special Conference Edition November, 2017 Zooplankton Sampling and Analysis

Zooplankton samples were collected with silk plankton net of $25 \mathrm{~cm}$ diameter of $70 \mathrm{~cm}$ meshes attached with a bottle of $50 \mathrm{ml}$ capacity at the base. The net was sunk just below the surface and then towed through a distance of $10 \mathrm{~m}$ horizontally. The content of the collected vial was then poured into plastic bottle of $50 \mathrm{ml}$ capacity and preserved in $4 \%$ formalin. Counting was done by shaking the preserved sample and pipetting $1 \mathrm{ml}$ of and then mounted on a compound microscope (Haris et al., 2000).

Identification was done based on standard identification guides of zooplankton. Alekseev (2002), Fernado (2002), and Kutikova (2002); Identification and classification of Freshwater invertebrates; The relative abundance of the various taxa was then calculated using the formular:

Where:

$$
\mathrm{No} / \mathrm{m}^{3}=\begin{aligned}
& C X V^{\prime} \\
& V^{\prime \prime} X V^{\prime \prime}
\end{aligned}
$$

$\mathrm{C}=$ number of organism counted

$V^{\prime}=$ Volume of the concentrated sample, $(\mathrm{ml})$

V"= Volume of water counted, $(\mathrm{ml})$

$\mathrm{V}$ "'= Volume of the grab sample, $\left(\mathrm{m}^{3}\right)$

To obtain organisms per liter, it is divided by 1000 (APHA, 2005)

\section{Data Analysis}

The results obtained were subjected to one way analysis of variance (ANOVA) to test significance at level of 0.05 between the physico-chemical factors and number of seasonal variations.
The distribution and abundance of the zooplankton communities in the reservoir was also assessed. Correlation analysis $(P \geq 0.05)$ was used to test the relationship between physicochemical parameters and zooplanktons distribution.

\section{RESULTS AND DISCUSSION}

The seasonal variation of the physicochemical parameters shows that $\mathrm{pH}$, Temperature, Chloride, Hardness and Alkalinity were not significant between the seasons $(P \leq 0.01)$ (Table1).

Based on season, all the species were observed to be more abundant in the wet season than in the dry season The number of cladocera, copepoda and rotifera were low in dry season with 578 organisms (45.76\%), 421 organisms $(43.09 \%)$ and $505(38.40 \%)$ respectively while in wet season were 685 organisms $(54.24 \%), 556$ organisms (56.91\%) and 810 organisms $(61.60 \%)$. The high population of zooplankton during the rainy season was traced to high population of phytoplankton food source which were highly abundant within the reservoir during the rains (Imoebe and Adeyinka, 2010). Mulayert et al. (2003) states that planktons usually reaches their peak source, low predation by fish during the rains as a result of their breeding could also have encouraged high population of the zooplanktons.

Zooplanktons in this study had positive relationship with calcium and $\mathrm{pH}$ of the reservoir. It was also observed by Mustapha (2008) in Assessment of water quality of Oyun Reservoir Offa Kwara State.

Table 1: Seasonal Variation of the Physico-chemical Parameters of Karidna Reservoir

\begin{tabular}{|c|c|c|c|c|}
\hline \multirow{2}{*}{ Parameter } & \multicolumn{2}{|l|}{ Season } & \multirow{2}{*}{ Total } & \multirow{2}{*}{$P$ value } \\
\hline & Dry & Wet & & \\
\hline $\mathrm{pH}$ & $7.41 \pm 0.04$ & $7.57 \pm 0.15$ & $7.49 \pm 0.08$ & $0.329 \mathrm{~ns}$ \\
\hline Temp $\left({ }^{\circ} \mathrm{C}\right)$ & $27.78 \pm 0.40$ & $28.19 \pm 0.44$ & $27.99 \pm 0.29$ & $0.497 \mathrm{~ns}$ \\
\hline $\mathrm{EC}(\mu \mathrm{S} / \mathrm{cm})$ & $58.97 \pm 1.35$ & $50.53 \pm 1.59$ & $54.75 \pm 1.17$ & $0.000^{* *}$ \\
\hline TDS (ppm) & $31.53 \pm 0.89$ & $24.97 \pm 0.76$ & $28.25 \pm 0.72$ & $0.000^{* *}$ \\
\hline Transparency $(\mathrm{cm})$ & $31.78 \pm 0.89$ & $24.65 \pm 0.76$ & $28.22 \pm 1.07$ & $0.001^{* *}$ \\
\hline $\mathrm{Cl}(\mathrm{mg} / \mathrm{L})$ & $3.23 \pm 0.15$ & $3.21 \pm 0.19$ & $3.22 \pm 0.12$ & $0.912 \mathrm{~ns}$ \\
\hline $\mathrm{PO}_{4^{-}}(\mathrm{mg} / \mathrm{L})$ & $0.18 \pm 0.01$ & $0.11 \pm 0.01$ & $0.14 \pm 0.01$ & $0.000^{* *}$ \\
\hline $\mathrm{NO}_{3}(\mathrm{mg} / \mathrm{L})$ & $0.27 \pm 0.01$ & $0.20 \pm 0.01$ & $0.24 \pm 0.01$ & $0.000^{* *}$ \\
\hline $\mathrm{SO}_{4}(\mathrm{mg} / \mathrm{L})$ & $0.07 \pm 0.002$ & $0.12 \pm 0.02$ & $0.09 \pm 0.01$ & $0.004^{* *}$ \\
\hline Hardness (mg/L) & $135.2 \pm 4.8$ & $126.4 \pm 7.6$ & $130.8 \pm 4.4$ & $0.311 \mathrm{~ns}$ \\
\hline $\mathrm{Ca}(\mathrm{mg} / \mathrm{L})$ & $2.43 \pm 0.10$ & $2.85 \pm 0.18$ & $2.64 \pm 0.10$ & $0.042^{*}$ \\
\hline Alkalinity (mg/L) & $3.89 \pm 0.27$ & $3.71 \pm 0.18$ & $3.80 \pm 0.16$ & $0.565 \mathrm{~ns}$ \\
\hline $\mathrm{DO}(\mathrm{mg} / \mathrm{L})$ & $5.49 \pm 1.88$ & $4.00 \pm 0.20$ & $4.74 \pm 0.15$ & $0.000^{* *}$ \\
\hline $\mathrm{BOD}(\mathrm{mg} / \mathrm{L})$ & $2.48 \pm 0.09$ & $3.28 \pm 0.09$ & $2.88 \pm 0.07$ & $0.000^{* *}$ \\
\hline
\end{tabular}

** - highly significant at $\mathrm{P} \leq 0.01$, Non-significant at $\mathrm{P}>0.01$ 
Special Conference Edition November, 2017

Table 2: Seasonal Abundance of Zooplankton Based on Families and Species

\begin{tabular}{lllll}
\hline Family & Species & Dry (\%) & Wet (\%) & Total (\%) \\
\hline Cladocera & Bosmina spp. & $156(36.11)$ & $276(63.89)$ & $432(12.15)$ \\
& Daphnia spp. & $146(52.14)$ & $134(47.86)$ & $280(7.88)$ \\
& Diaphaesoma spp. & $117(33.52)$ & $232(66.48)$ & $349(9.82)$ \\
& Macrothrix spp. & $37(100.00)$ & $0(0.00)$ & $37(1.04)$ \\
& Simocephalus spp. & $71(100.00)$ & $0(0.00)$ & $71(2.00)$ \\
& Polyphemus spp. & $27(100.00)$ & $0(0.00)$ & $27(0.76)$ \\
Copepoda & Eurycercus spp. & $24(35.82)$ & $43(64.18)$ & $67(1.88)$ \\
& & $578(45.76)$ & $685(54.24)$ & $1263(35.53)$ \\
& Cyclops & $152(40.21)$ & $226(59.79)$ & $378(10.63)$ \\
& Diatomas spp. & $133(50.00)$ & $133(50.00)$ & $266(7.48)$ \\
Rotifera & Nauphilii & $102(48.34)$ & $109(51.66)$ & $211(5.94)$ \\
& Eubranchipus spp. & $34(27.87)$ & $88(72.13)$ & $122(3.43)$ \\
& & $421(43.09)$ & $556(56.91)$ & $977(27.48)$ \\
& Branchionus spp & $159(41.09)$ & $228(58.91)$ & $387(10.89)$ \\
& Kellicottia spp. & $98(28.65)$ & $244(71.35)$ & $342(9.62)$ \\
& Keratella spp. & $112(44.62)$ & $139(55.38)$ & $251(7.06)$ \\
Season Total & $63(100.00)$ & $0(0.00)$ & $63(1.77)$ \\
& Lecane spp. & $73(26.84)$ & $199(73.16)$ & $272(7.65)$ \\
& Trichocera spp. & $\mathbf{5 0 5 ( 3 8 . 4 0 )}$ & $\mathbf{8 1 0 ( 6 1 . 6 0 )}$ & $1315(36.99)$ \\
& & $1504(42.31)$ & $2051(57.69)$ & 3555 \\
\hline
\end{tabular}


Special Conference Edition November, 2017

Correlation of Phyisco-chemical Parameters and the zooplanktons

\begin{tabular}{|c|c|c|c|c|c|c|c|c|c|c|c|c|c|c|c|c|c|}
\hline & Cladocera & Copepods & Rotifers & $\mathrm{Cl}$ & PO4 & $\mathrm{NO} 3$ & SO4 & Hardness & $\mathrm{Ca}$ & Alkalinity & Temp & $p H$ & $E C$ & TDS & Transp. & DO & $B O D$ \\
\hline Cladocera & 1 & & & & & & & & & & & & & & & & \\
\hline Copepods & $0.7894^{*}$ & 1 & & & & & & & & & & & & & & & \\
\hline Rotifers & $0.8159^{*}$ & $0.6157^{*}$ & 1 & & & & & & & & & & & & & & \\
\hline $\mathrm{Cl}$ & 0.4154 & 0.0885 & 0.4403 & 1 & & & & & & & & & & & & & \\
\hline PO4 & -0.2054 & -0.1495 & -0.3141 & 0.1290 & 1 & & & & & & & & & & & & \\
\hline NO3 & -0.0522 & -0.1736 & -0.2807 & 0.2085 & $0.5580^{*}$ & 1 & & & & & & & & & & & \\
\hline SO4 & 0.2356 & 0.4510 & 0.3016 & -0.1771 & -0.2552 & -0.5364 * & 1 & & & & & & & & & & \\
\hline Hardness & $0.5715^{*}$ & 0.4545 & 0.3861 & $0.7144^{*}$ & 0.2522 & $0.5853^{*}$ & -0.0649 & 1 & & & & & & & & & \\
\hline $\mathrm{Ca}$ & $0.5224^{*}$ & $0.5358^{*}$ & $0.6411^{*}$ & $0.5431^{*}$ & -0.3169 & -0.2551 & 0.4713 & $0.5285^{*}$ & 1 & & & & & & & & \\
\hline Alkalinity & $0.5709^{*}$ & 0.2445 & 0.3111 & $0.5222^{*}$ & -0.0386 & 0.3129 & 0.0182 & $0.6323^{*}$ & 0.2879 & 1 & & & & & & & \\
\hline Temp & $-0.6452^{*}$ & -0.3830 & -0.4869 & -0.1423 & -0.0268 & -0.2973 & -0.1618 & -0.4583 & -0.3603 & -0.3968 & 1 & & & & & & \\
\hline $\mathrm{pH}$ & $0.6412^{*}$ & 0.3891 & $0.6419^{*}$ & $0.6272^{*}$ & -0.0190 & -0.2601 & 0.2246 & 0.3690 & $0.6769^{*}$ & 0.2339 & $-0.5122^{*}$ & 1 & & & & & \\
\hline EC & -0.3038 & -0.3998 & -0.3586 & -0.2965 & 0.4983 & $0.6722^{*}$ & $-0.6682^{*}$ & -0.0834 & $-0.6551^{*}$ & -0.2260 & -0.1877 & -0.3889 & 1 & & & & \\
\hline TDS & -0.1987 & -0.2458 & -0.2969 & -0.2722 & $0.6550^{*}$ & $0.6213^{*}$ & $-0.5583^{*}$ & -0.0103 & $-0.6281^{*}$ & -0.1554 & -0.2296 & -0.2917 & $0.8980^{*}$ & 1 & & & \\
\hline Transparency & -0.2980 & $-0.5575^{*}$ & -0.4291 & 0.1051 & 0.4871 & $0.7166^{*}$ & -0.4483 & 0.1436 & $-0.5965^{*}$ & 0.3358 & 0.0337 & -0.4193 & $0.5645^{*}$ & $0.5141^{*}$ & 1 & & \\
\hline DO & 0.1449 & -0.1670 & -0.1875 & 0.1742 & 0.2345 & $0.8437^{*}$ & -0.3984 & 0.4953 & -0.1757 & 0.4991 & $-0.5411^{*}$ & -0.0920 & $0.5387^{*}$ & 0.4089 & $0.6409^{*}$ & 1 & \\
\hline BOD & -0.2014 & -0.2164 & $-0.5243^{*}$ & -0.4468 & 0.1579 & 0.3954 & -0.4951 & -0.2583 & $-0.7290^{*}$ & 0.0052 & 0.0398 & -0.4859 & $0.6442^{*}$ & $0.5011^{*}$ & $0.5076^{*}$ & 0.4590 & 1 \\
\hline
\end{tabular}

Correlation is significant at $\mathrm{P} \geq 0.05$ levels. $\mathrm{NOTE} \mathrm{cl}=$ chloride $\mathrm{BOD}=$ Biological Oxygen Demand $\mathrm{DO}=$ Dissolved oxygen $\mathrm{PO}_{4^{-}}=\mathrm{Phosphate}^{-} \mathrm{SO}_{4^{-}}=$ Sulphate EC= Electrical conductivity $\mathrm{Ca}=$ Calcium TDS= Total dissolved solids Temp= Temperature 


\section{Special Conference Edition November, 2017}

\section{CONCLUSION}

Zooplankton is considered as the chief index of the utilization of aquatic biotope at the secondary trophic level. The intensity of zooplankton aggregation largely depends on different factors including different water quality parameters as well as their ability to counter dispersion, phytoplankton growth, grazing rates, predator/prey relationship and reproductive strategies. The present study revealed that almost all of the water quality parameters exhibit either positive or negative correlation with zooplankton distribution in the study site. In addition, the zooplankton is normally utilized by higher trophic levels, particularly by pelagic fish species and larvae. In the upwelling areas, the zooplankton standing stock (biomass) is higher and zooplankton community is dominated by herbivores. Zooplankton constitutes the main

\section{REFERENCES}

Alekseev,(2002) "Copepoda," in A Guide to Tropical Freshwater Zooplankton:

Identification Ecology and Impact on Fisheries, C. H. Fernando, Ed., pp. 123187, Backhuys Publishers, Leiden, The Netherlands.

APHA (2005). Standard methods for the examination of water and waste water.21st Edn., Washington, D. C.

Beyruth, Z. (2000). Periodic disturbances, trophic gradient and phytoplankton characteristics related to cyanobacterial growth in Guarapiranga reservoir. Sao Paulo Stae, Brazil. Hydrobiologia Journal. 424: $51-60$

Fernando, C.H. (2002). A Guide to Tropical Freshwater Zooplankton; Identification, Ecology and Impact on Fisheries. Backhuys Publishers, Leiden.p. 291.

Harris, R.P, Wiebe, P.H., Lenz, J., Skjoidal, H.R and Huntly, M.(2000). Zooplankton Methodology Manual. Academic Press, Harcourt Place, 32 Jamestown Road, London NW17BY, UK Health/Globassesment/Global TOC.htm.

Imoobe, T. O. T. and Adeyinka, M. L. (2010). Zooplankton-based assessment of the trophic state of a tropical forest river. International Journal of Fisheries and Aquaculture, 2(2): 64-70.

Kutikova L.A(2002). Rotifera In: Fernado.CH(ed). A guide to Tropical Freshwater Zooplankton; Identification, Ecology and Impact on Fisheries. Backhuys Publisher, Leiden pp. 23-68. food item of several fish species. The pelagic fishes migrate in shoals to the feeding ground rich in food and therefore zooplankton can be used as indicators of rich potential fishing grounds.

\section{Recommendations}

- Farmers and students around the reservoir should be enlightened on the effects of their activities into the water body especially application of inorganic fertilizers and pesticides, irrigation, washing when the water recedes.

- More studies should be carried out to identify the zooplankton composition using polymerase Chain Reaction (PCR) and other Taxonomic identification methods that are not used during this work.

Mustapha, M.K. (2008). Assessment of the Water Quality of Oyun Reservoir, Offa, Nigeria, using Selected Physico-chemical Parameters. Turkish Journal of Fisheries and Aquatic Sciences, 8, 309-319.

Muylaert, K., Declerck, S. Geenens, V. Wichelen, J.V. Deegans, H. Vandekerkhove, J. Gucht, K.V. Vloemans, N. Rommens, W. Rejas, D. Urrutia, R. Sabbe, K. Gills, M. Decleer, K. Meester, L.D. \& Vyverman, W.(2003).Zooplankton, Phytoplankton and the Microbial food web in two turbid and two clear shallow lakes in Belgium. Journal of Aquatic Ecology 9(37): 137150.

Mustapha, M.K. (2011). Perspectives in the Limnology of Shallow Tropical African Reservoirs in Relation to Their Fish and Fisheries. Journal of Transdisciplinary Environmental Studies 10(1):16-23

Thirupathaiah M.(2012)Diversity of zooplankton in lower manair reservoir, Karimnagar, AP India, Indian Reserved. Biological Sciences., 1(7),27-32

Venkatesharaju K., Ravikumar.p., Somashikar (2010). Physicochemical and Bacteriological Investigation on the river Cavvery of kollegal stretch in Karnataka, Journal of Science Engineering and technology, 6(1). Pp 50-59 